\title{
EUA x HUAWEI: A IMPORTÂNCIA ESTRATÉGICA DA TECNOLOGIA 5G PARA O PODER GLOBAL.
}

\author{
Marcus Vinicius da Silva Tavares ${ }^{1}$
}

\begin{abstract}
Resumo: Desde o ano de 2019, a tecnologia 5G vem ganhando cada vez mais espaço nos noticiários econômicos e políticos, bem como nos estudos acadêmicos. Tal fato é devido também ao romper de uma nova era das tecnologias de informação e comunicação, no qual é fundamental para um novo paradigma industrial. Contudo, se deve em grande medida às sanções impostas pelos EUA à Huawei, sob a alegação de espionagem em conjunto com o Estado chinês. Tais acusações levam a indagações quantos aos interesses por trás das sanções estadunidenses. Ao mesmo tempo em que nossos olhos se voltam com facilidade e encanto às aplicabilidades que nos são anunciadas na automação de indústrias, veículos sem condutores, casas e cidades inteligentes; as aplicabilidades militares são igualmente vastas e capazes de influenciar de forma ainda imensurável o tabuleiro do poder global. Dentro desse cenário, o presente trabalho objetiva investigar as aplicabilidades econômicas e militares da tecnologia $5 \mathrm{G}$ e como elas se correlacionam no campo do conflito geopolítico entre China e EUA num contexto de disputa global.
\end{abstract}

Palavras-chave: China; Trump; Cibersegurança.

Abstract: Since 2019, the $5 \mathrm{G}$ technology is getting more attention in the economic and political news, as well as in the academic field. These factors are also brought by the new age of information and communication technology (ICT) which are vital to the new industrial paradigm. But which is the fault of, most of all, of the sanctions imposed by the US to Huawei, under the allegation of espionage together with the Chinese State. Those accusations bring questions about the real interesses behind the American's sanctions. At the same time that our eyes are easily brought to the appeal and applicabilities that are announced in the automation of the industries, with vehicles without drivers and intelligent houses and cities; the military applications are equally vast and capable of influencing in a more immeasurable manner the global power board as it is drawn. In this scenario, the present work searches to investigate the economical and military applicabilities of the $5 \mathrm{G}$ technology and the way these technologies are correlated in the field of geopolitical global dispute between China and the USA.

Keywords: China; Trump; Cybersecurity.

\footnotetext{
${ }^{1}$ Mestrando em Economia Política Internacional (PEPI/UFRJ).
} 


\section{Introdução}

A crescente dos indicadores econômicos chineses fala por si só quanto a sua expressividade. Entre os anos de 1983 e 2014, o produto interno bruto (PIB) da China passou de uma participação de $2,5 \%$ no PIB mundial para $13,5 \%$. No quesito exportações, sua participação no saldo mundial mais que decuplicou, passando de 1,2\% para 12,1\% no mesmo período. "O país transformou-se na 'fábrica do mundo'. Alçou-se à posição de segunda maior economia, de maior exportador, de segundo maior importador e de detentor das maiores reservas internacionais, atualmente na faixa de US\$ 3,8 trilhões." (Leão, 2015)

Nesse sentido, o progresso tecnológico alcançado após políticas de Estado nas duas primeiras décadas desse século tem combinado estratégias de integração nas cadeias globais de valor com trajetórias de formação de "campeões nacionais" em setores que suas lideranças julgam estratégicos. Hodiernamente, a China tenta construir uma base de inovação nacional que permita às empresas nacionais deterem a propriedade intelectual dos produtos e serviços comercializados nas cadeias globais (Nogueira 2015). Intenções estas claramente expostas no Made in China 2025, um plano estratégico do governo central chinês que visa orientar a modernização industrial chinesa e diminuir sua dependência de tecnologia estrangeira.

Um dos frutos que surgiram do investimento chinês em novas tecnologias é a vanguarda da Huawei, empresa chinesa, quanto a tecnologia $5 \mathrm{G}$ - a nova geração de rede móvel, capaz de prover significativas melhorias na cobertura, disponibilidade e velocidade de conexão, permitindo também uma maior densidade de dispositivos conectados. A tecnologia $5 G$ com sua capacidade de fluxos de dados praticamente instantâneos é peça chave na Indústria 4.0, também chamada de a quarta revolução industrial. A Indústria 4.0 é caracterizada pelo alto nível de incorporação da robótica, de tecnologias de informação, de telecomunicações e de inteligência artificial às atividades industriais - o que resulta em um alto nível de automação nas linhas de produção, devido a integração mais fluída e "natural" entre equipamentos. Atualmente a Huawei, gigante chinesa das telecomunicações, detém a melhor e mais barata versão da tecnologia de rede $5 \mathrm{G}$. 
Ao longo de toda a história humana, o desenvolvimento de novas tecnologias acabou por conferir vantagens a quem primeiro se mostrou hábil a propulsionar seus interesses através dos novos inventos. A partir da Primeira Revolução Industrial as inovações tecnológicas se tornaram cada vez mais frequentes e impactantes, passando em momentos específicos - tidos como marcos de uma revolução - a representar uma profunda transformação nos modelos de produção. O Estado que irrompe a nova era tecnológica na qualidade de pioneiro passa a ter vantagem produtiva e maior capacidade de internalizar capitais dado a alta rentabilidade que oferece.

Desde 2019, a Huawei sofre impactantes sanções por parte do governo estadunidense, sob a alegação de espionagem. Segundo o governo norteamericano, a tecnologia da empresa chinesa oferece riscos aos EUA, uma vez que carregaria em si uma porta de acesso aos dados de seus usuários para uso da inteligência do Estado chinês, o que ofereceria riscos tanto aos usuários como também ao complexo militar dos EUA. Mesmo que tal lacuna na segurança nunca tenha sido comprovada, a Huawei foi adicionada à lista negra do governo dos EUA. Tal medida impactou os negócios de empresas gigantes do setor de telecomunicação dos EUA que se viram impedidas de fazerem negócios com a segunda maior produtora de smartphones do mundo.

Os EUA sempre estiveram na vanguarda tecnológica, desde que ascendeu ao posto de desafiante da hegemonia inglesa, e isso é especialmente o caso em relação à infraestrutura da informação. $O$ atual momento se delineia decisivo. As razões pelas quais os EUA aplicam sanções comerciais à Huawei, sob a alegação de proteção à soberania nacional, soam como verdadeiras, porém, por motivos mais abrangentes do que os alegados. $\mathrm{O}$ artigo dialogará com algumas interpretações de importantes teóricos quanto ao momento, de forma a entender como as aplicabilidades e os efeitos da tecnologia $5 G$ no cenário internacional se correlacionam com interesses mais amplos do que os alegados. 


\section{1. $O$ caso EUA $X$ Huawei}

A rede $5 G$ não configura uma inovação acabada em si mesma, não se limitando a uma rede de telefonia móvel, sendo apontada como a base da infraestrutura sobre a qual funcionará todo um complexo industrial que reduzirá os custos de produção e agilizará todos os pontos da cadeia produtiva. A tecnologia $5 G$ com sua capacidade de fluxos de dados praticamente instantâneos (cerca de dez vezes mais rápida que a conexão 4G) é peça chave na Indústria 4.0, também chamada de a "Quarta Revolução Industrial". Como detalha Pires (2018, p.17): "A Internet está para a Quarta Revolução Industrial o que o motor a vapor e a eletricidade foram para a Primeira e a Segunda Revoluções Industriais, ou seja, uma tecnologia de propósito geral que tem seu uso disseminado pelos mais variados campos da economia e da sociedade."

\subsection{A Quarta Revolução Industrial e a tecnologia 5G}

A alta velocidade de conexão proporcionada pela tecnologia do $5 \mathrm{G}$ é fundamental para os três principais vetores tecnológicos que baseiam a Quarta Revolução Industrial - as tecnologias físicas, as tecnologias digitais e as biotecnologias. As tecnologias físicas compreendem áreas como a robótica avançada, veículos autônomos, manufatura aditiva ou impressão em 3D e o desenvolvimento de novos materiais (Pires, 2018).

Embora a inserção de robôs em linhas produtivas seja algo consolidado e que já não gere nenhuma estranheza, o uso esperado na indústria 4.0 vai muito além do que fora no passado. Se em seu uso inicial os robôs eram utilizados em espaços apartados do convívio com os trabalhadores, o que se espera para os próximos anos são que tarefas que exigem mobilidade e jogo de articulações e que outrora requeriam trabalhadores para serem desempenhadas - sejam executadas por robôs. Passando assim, a se ter linhas de montagem operadas com robôs que possuem leitura espacial por escaneamento e que podem ser programados sem auxílio de um especialista, bastando um operário do próprio 
chão da fábrica (Pires, 2018, p.19). Outros aspectos da robótica avançada são a capacidade de controle de cada robô ou equipamento automatizado via Internet e a capacidade dessas máquinas interagirem entre si dentro de um plano estabelecido pelos engenheiros; existindo a capacidade que cada equipamento corrija suas atuações em caso de mudanças inesperadas no processo (Pires, 2018, p.20).

A Quarta Revolução Industrial também possibilitará o desenvolvimento e aprimoramento de veículos autônomos, indo além de "vants" (veículos aéreos não tripulados, conhecidos como drones em inglês), levando ao desenvolvimento de automóveis e caminhões capazes de deslocarem-se de modo autônomo pelas ruas e rodovias: "Graças a equipamentos e softwares de escaneamentos de ambiente, de posicionamento e de dirigibilidade capazes de 'aprender' com experiências que o veículo enfrenta no trânsito, armazenando eventuais erros e corrigindo em suas versões atualizadas" (Pires, 2018, p.20).

Outra área pertencente à chamada $4^{\text {a }}$ Revolução Industrial é a de desenvolvimento de novos materiais. O intuito é o desenvolvimento de novos materiais mais eficientes que os utilizados até o momento, reduzindo custos produtivos e possibilitando acréscimo de segurança. Sendo esse desenvolvimento o fruto de pesquisas de centros universitários, possibilitadas pelo barateamento dos custos de armazenamento de informação e pela capacidade de processamento de dados por sistemas de Inteligência Artificial (IA). O que nos leva ao vetor das tecnologias digitais.

As tecnologias digitais se referem à Inteligência Artificial, à Internet das Coisas, à análise de Big Data, às moedas virtuais e à economia sob demanda. A alta velocidade de conexão proporcionada pela Internet $5 G$ possibilitará a integração de uma série de dispositivos como máquinas e equipamentos industriais, equipamentos urbanos (como iluminação pública e semáforos), computadores pessoais, telefones celulares, tablets, automóveis, além de uma variedade de eletrodomésticos que podem ser conectados em rede e controlados à distância por meio da internet das coisas (Pires, 2018, p.22). Estima-se, segundo pesquisa realizada pelo World Economic Forum (WEF, 2015), que em 2025 o mundo chegue próximo de 1 trilhão de dispositivos conectados à Internet; resultando, como detalha Pires (2018), em uma maior 
eficiência, aumento de produtividade, melhoria da qualidade de vida, controle dos impactos das atividades produtivas sobre o meio ambiente, menor custo de prestação de serviços, maior segurança frente a possibilidade de monitoramento virtual, maior eficiência logística dentro e fora das empresas, maior facilidade para a concepção de produtos ajustados às necessidades de cada cliente etc. A existência dessa grande conexão de dispositivos leva a um novo e mais alto patamar de dados circulantes na Internet, o que leva ao desafio de tornar todos esses dados circulantes em informações úteis. Para tal a "análise de Big Data" configura-se como importante instrumento da Quarta Revolução Industrial (Pires 2018. p.22).

Segundo Pires (2018), os sistemas de IA passam a ser cada vez mais capazes de deduzir e inferir novos padrões a partir de conhecimentos preexistentes e utilizar métodos de representação e manipulação capazes de resolver problemas complexos de caráter qualitativo, ou seja, que não são passíveis de regras ou leis previamente ensinadas ao computador (Pires, 2018, p.23). Como utilidade a esse processamento de dados em tamanha grandeza temos, por exemplo, a potencialização de pesquisas científicas, o aprimoramento de sistemas de gestão, a precificação de ativos (como ações e moedas), acréscimo de eficiência na gestão de tráfego e tráfico das cidades, a definição mais exata de padrões de consumo de grupos e indivíduos.

Outro aspecto importante das tecnologias digitais diz respeito à formação de uma on demand-economy, ou uma economia sob demanda (sob medida). Cada vez mais, sítios eletrônicos e aplicativos de Internet tenderão a moldar novas formas de interação humana voltadas a troca de bens e serviços. Para os próximos anos, são esperados um aumento do chamado consumo colaborativo, onde determinados bens e ideias passam a ser compartilhados mediantes custos menores do que os correlatos no mercado (Pires 2018, p23).

O alto tráfego de dados, juntamente com a análise de Big Data e a Inteligência Artificial, aliados a capacidade da Indústria 4.0 de rápida adaptação nas linhas de produção a novas demandas, tende levar a economia sob demanda para um novo patamar e de várias formas ainda não imaginadas. As biotecnologias são o terceiro vetor da Quarta Revolução Industrial, que compreendem o uso de tecnologias de sequenciamento genético, da Biologia 
sintética por meio de manipulação do DNA, da combinação de edição de genes e de impressoras 3D, das Ciências do Cérebro e do Biomimetismo no processo de desenvolvimento de novos materiais. Tal realidade abre perspectivas inovadoras no cuidar da saúde, na produção de alimentos, na criação de próteses, na interação entre ondas cerebrais e objetos externos ao corpo humano e no desenvolvimento de materiais poupadores de energia ou de estruturas inspiradas nos seres vivos - o que tende a impulsionar novas formas de produção, de construção civil e de projetar. Sendo os avanços da informática de suma importância para os avanços dos experimentos em laboratórios, no desenvolvimento de instrumentos de medição cada vez mais sofisticados e no desenvolvimento de nanoestruturas (Pires, 2018). Tais avanços são possíveis devido a capacidade de armazenamento e processamento de dados alcançados nas últimas décadas; sendo a tendência que tais dados aumentem abruptamente com o ganho de velocidade de conexão ofertado pela tecnologia $5 \mathrm{G}$, levando a um progressivo avanço exponencial das biotecnologias.

Como se pôde ver, a tecnologia $5 \mathrm{G}$ se entrelaça com diversos avanços tecnológicos, uma vez que fornece a velocidade de conexão necessária para a interligação dos mais distintos equipamentos e também possibilita um nível antes impensável de armazenamento de dados e de realização do seu processamento. Tais possibilidades alavancadas pela tecnologia $5 G$ tendem a conduzir a economia mundial a um novo nível de ganhos econômicos, elevando a importância chinesa no âmbito mundial caso o padrão da tecnologia $5 G$ da Huawei de fato se estabeleça como padrão global dominante. Sendo assim, a vanguarda no tocante a tecnologia $5 \mathrm{G}$ possibilitaria incrementos de ordem econômica devido a diminuição de custos produtivos, bem como oriundos da exportação de equipamentos necessários a infraestrutura para a construção de redes 5G. Podendo tal cenário resultar em um aumento de poder políticoeconômico no âmbito internacional em decorrência de um aumento de fluxos de capitais para a economia dos países em vanguarda. Possibilidade que se mostra suficiente para que os EUA usem o poder que detêm no tabuleiro global, de modo a aplicar sanções diretas contra a Huawei e tentar frenar os acordos de outros países para a aquisição da tecnologia $5 G$ da Huawei - como se viu nos 
esforços norte-americanos junto a países europeus para banirem as compras da tecnologia chinesa (Wintour, 2020).

As sanções econômicas impostas à Huawei por parte do governo norteamericano se deram sobre a alegação de espionagem. Cabe salientar que acusações desse tipo não são novas. A Huawei já sofreu acusações de espionagem industrial pela Motorola e pela Cisco, gigantes do ramo de telecomunicações (Segal, 2016). No ano de 2012, a Huawei foi o centro de investigações conduzidas por agências de inteligência dos EUA que não encontraram evidências de espionagem ativa, mas que desaconselharam o emprego de equipamentos de redes da Huawei pela existência de vulnerabilidades nos mesmos que poderiam trazer sérios riscos. Um relatório do Congresso dos EUA, sobre o mesmo caso, alertou contra a permissão para as empresas chinesas Huawei e ZTE fornecerem infraestrutura crítica de telecomunicações. Bill Plummer - porta-voz da Huawei nos EUA - alegou que: "A Huawei é uma multinacional independente de US\$ 32 bilhões que não colocaria em risco seu sucesso ou a integridade das redes de seus clientes para qualquer governo ou terceiro." (Menn, 2012). Por outro lado, em 2014, a Huawei acusou a Agência de Segurança Nacional dos EUA (NSA) de a espionar (Segal, 2017).

\subsection{O realismo do governo Trump e a perspectiva militar da tecnologia 5G}

Fiori (2004) enxerga que a crise dos anos 1970 e a "expansão financeira" posterior, junto ao fim da Guerra Fria, transferiu aos EUA uma centralidade militar, monetária e financeira sem precedentes na história da economia-mundo capitalista. Se, para muitos acadêmicos, a vitória sobre a URSS configuraria o "fim da história" (Fukuyama, 1992), o que na prática se viu foi que enquanto expandia seu poder, os EUA foram decisivos no ressurgimento da Rússia e no salto econômico da China (Fiori, 2018). Para ele, as duas potências utilizam as regras do sistema interestatal, e de suas normas, de seus regimes e de suas instituições, passando a questionar o novo mundo liberal e unipolar americano em particular, a Rússia no campo militar e a China no campo econômico. Os dois 
países, portanto, começaram a ameaçar o poder global norte-americano, obrigando os Estados Unidos a darem uma guinada de 180 graus em sua estratégia internacional (Fiori, 2018). Tal guinada resulta na adoção do isolacionismo e do internacionalismo unilateral.

As instabilidades sistêmicas - mesmo depois de os EUA adquirirem uma concentração de poder sem precedentes -, aliadas a ascensão econômica chinesa, têm fomentado o debate sobre o futuro da ordem internacional. Nomes importantes dentro da tradição geopolítica estadunidense e de diferentes escolas teóricas, como Henry Kissinger e Zbigniew Brzezinski, deram suas contribuições ao debate e reforçaram a sua preocupação quanto a importância de uma política externa assertiva por parte dos EUA quanto à China.

Henry Kissinger (2014) cita a importância de um acerto da política externa na região da Eurásia. Em sua reflexão quanto ao balanço de poder, enxerga que a essência da construção de uma ordem mundial reside no fato de que nenhum país sozinho, nem a China, nem os Estados Unidos, está em condições de exercer a liderança mundial, como o fez os Estados Unidos no período imediatamente posterior à Guerra Fria, quando prevaleceu material e psicologicamente.

Brzezinski (2012) retoma o conceito de Eurásia e reforça a importância da atuação dos EUA na região; além disso observa que houve uma falta de capacidade dos EUA em reformular a arquitetura de poder da região no vácuo de poder que surgiu no pós Guerra Fria. O autor afirma que o esforço geoestratégico de longo prazo deve se concentrar na Eurásia como um todo. Sua combinação de motivações geopolíticas competitivas, poder político, e dinamismo econômico fazem do enorme continente transeurasiano a arena central dos assuntos mundiais (Brzezinski, 2012; Padula, 2018).

Para Brzezinski, os EUA devem separar quais aspectos da política externa da China são ambições inaceitáveis e representam uma ameaça direta aos interesses estadunidenses vitais, e que aspectos refletem novas realidades geopolíticas e econômicas históricas que podem ser acomodadas, no entanto, com relutância, sem danos aos principais interesses dos EUA. O autor entende que a política de "guerra ao terror" de George W. Bush transformou os EUA em um "Estado cruzadista", resultando em um despreparo frente aos novos desafios 
geopolíticos do século XXI e com uma carente visão estratégica de longo prazo, acarretando uma deterioração do seu poder relativo (Brzezinski, 2012; Padula 2018).

Outro importante teórico é John Mearsheimer (2018), o qual aponta que grandes potências raramente estão em uma posição para prosseguir uma política externa liberal em grande escala. A existência de duas ou mais potências grandes no mundo acaba por forçar que se preste muita atenção a sua posição no equilíbrio global de poder e a agir de acordo com os ditames do realismo. A natureza anárquica hobbesiana do sistema internacional faz com que grandes potências liberais regularmente falem como liberais e ajam como realistas. Porém, num contexto unipolar - sem a ameaça de outra grande potência - podese abraçar a hegemonia liberal.

Contudo, Mearsheimer (2018) ressalta a fragilidade do liberalismo frente ao realismo - frente a sua ótica de autopreservação - e também frente ao nacionalismo - no qual ressalta que ao se confrontar com o liberalismo, quase sempre sai vencedor. $O$ autor recomenda que a futura condução da política externa americana deve: em primeiro lugar, descartar suas grandes ambições de hegemonia liberal - visto que esta política não é apenas propensa ao fracasso, ela tende a envolver o mercado americano militar em guerras caras que acaba perdendo; em segundo lugar, Washington deveria adotar uma política externa mais contida, baseada no realismo e em uma clara compreensão de como o nacionalismo limita a margem de manobra de uma grande potência.

Como podemos ver numa breve revisão teórica de alguns nomes importantes da geopolítica estadunidense há uma proximidade de ideais entre os autores e as ideias e diretrizes da política externa norte-americana adotadas a partir do governo Donald Trump. Se fazendo presente uma forte revisão quanto a difusão do universalismo dos princípios estadunidenses; o reconhecimento do sistema internacional como um espaço de competição permanente pelo 'poder global' entre os Estados nacionais; a necessidade de as negociações com outros Estados serem pautadas unicamente pelos interesses nacionais e sempre a partir de uma 'posição de força'; bem como a importância conferida à China.

Comumente, a figura tida como controversa do presidente Trump acaba por dificultar a percepção que suas ideias vão além da sua própria figura e que, 
na verdade, representam grupos e interesses da política interna estadunidense - como alguns documentos de organismos da política estadunidense demonstram. A Plataforma do Partido Republicano (PPR), publicada na convenção nacional do partido antes da confirmação da vitória de Donald Trump nas primárias, delineia as principais pautas e prescrições encontradas na política externa de Donald Trump. Os republicanos se comprometem em "reestabelecer o poder bélico norte-americano como o maior do mundo, com vasta superioridade sobre qualquer outra nação ou grupo de nações do mundo" (PPR 2016, p. 41). A conjuntura internacional é descrita como eminentemente perigosa, na qual Rússia e China avançam seus interesses. Na parte prescritiva do documento, em uma referência aos anos 1980, os republicanos advogam uma resposta conforme a de Ronald Reagan, resumida na expressão "paz através de força" (peace through strength, em inglês), um dos quatro pilares formulados no relatório Estratégia de Segurança Nacional da Administração de Donald Trump, publicada em dezembro de 2017.

O National Security Strategy de 2017 (NSS-2017) configura-se como um documento ainda mais importante, visto ser um documento oficial de governo, preparado em conjunto pelo Departamento de Estado, pelo Pentágono, pela CIA (Central Intelligence Agency), por todas as agências de informação do governo estadunidense, junto com seu Departamento de Comércio e com a sua Secretaria do Tesouro. Por seu teor, pode-se entender que o documento estipula diretrizes que não se restringem apenas a governos republicanos, baseando também governos democratas nos próximos anos. Como apontado por Fiori (2018), o NSS-2017 se situa na tradição do realismo internacional de Edward Carr e Hans Morghentau, bem como do "realismo ofensivo" de John Mearsheimer do final do século XX. O documento rompe com o "cosmopolitismo liberal", introduzido no cenário internacional pelo presidente dos EUA Woodrow Wilson no Pós I Guerra Mundial; configurando-se assim, uma ruptura com o que foi a política externa dos EUA do século XX (Fiori, 2018). O documento expressa o reconhecimento do Sistema Internacional como um espaço de competição permanente pelo "poder global" entre os Estados nacionais soberanos; reconhece que os valores estadunidenses não são universais e nada assegura que um dia serão; declara que a competição e as negociações com outros 
Estados serão pautados unicamente pelos interesses nacionais e sempre a partir de uma "posição de força" , o que inclui o uso de armas - se necessário; propõe a retomada da liderança tecnológica em todos os campos de conhecimento, em particular no campo da guerra e dos armamentos atômicos; e assume o direito de usar sua economia e suas sanções econômicas como instrumentos de guerra (Fiori, 2018).

As sanções econômicas aplicadas pelo governo Trump contra a chinesa Huawei e mantidas até o momento pelo governo Biden, bem como as pressões político-econômicas sobre outros Estados, se adequam às diretrizes do NSS2017, esse eivado das concepções do realismo tradicional. A ideia de luta pelo poder é notória no NSS-2017, sendo tal ideia condizente com a perspectiva realista de o cenário mundial ser uma arena pelo poder - como defende Hans Morghentau (2003, p.62):

Embora alguns antropólogos nos tenham mostrado que certos povos primitivos parecem estar isentos do desejo de poder, ninguém jamais nos revelou como o seu estado de espírito e as condições sob as quais eles vivem podem ser recriados numa escala mundial, de modo a eliminar do cenário internacional a luta pelo poder. Seria inútil, além de autodestrutivo, tentar libertar um ou outro povo do desejo de poder, enquanto ele permanecer vivo em outros. Se o desejo de poder não puder ser abolido em todos os cantos do mundo, aqueles que dele pudessem ficar curados seriam simplesmente vítimas do poder dos demais.

A percepção de uma guerra iminente que demanda preparação constante, se faz evidente nas diretrizes do documento norte-americano e guarda estrita afinidade com a importância conferida por Edward Carr ao instrumento militar como ultima ratio do poder. A importância conferida a guerra (ou a preparação para ela) pela teoria realista dentro do contexto internacional é justificada por Carr (1981), o qual entende que a guerra em potencial é um fator dominante na política internacional e que o poderio militar se torna um padrão aceito de valores políticos. Tendo toda grande civilização do passado desfrutado em sua época de uma superioridade militar. Sendo o status político atingido por qualquer sintoma de ineficiência ou despreparo militar (Carr 1981, p.144).

Esta percepção que as relações entre os países são dotadas de natureza conflituosa é ampliada no Realismo Ofensivo de Mearsheimer (2001, p.33), no qual os países procuram oportunidades para alterar o equilíbrio de poder a seu 
favor, adquirindo mais poder às custas de rivais em potencial. Para tal fim, são empregados meios econômicos, diplomáticos, militares; não importando se outros Estados o considerarão suspeitos ou mesmo hostis. Dentro dessa leitura, o ganho de poder de um estado é a perda de outro estado, grandes poderes tendem a ter uma mentalidade de soma zero quando lidam uns com os outros.

Como visto, o Realismo Ofensivo de Mearsheimer tem caráter ativo, uma vez que os Estados num cenário de prevenção de futuros conflitos buscam se valer de todas as oportunidades para reajustar o tabuleiro de poder de modo a alterar o equilíbrio de poder de forma positiva para si às custas de rivais potenciais. Ademais, o Realismo Ofensivo considera que os meios utilizados não se restringem ao bélico-militar, mas também se vale de meios econômicos e diplomáticos. Tal perspectiva multi-instrumentalista também se faz presente no documento, além de ser amplamente utilizado com ferramentas coercitivas ao redor do mundo, bem como no caso das sanções à Huawei.

O caso em tela se configura como uma resposta a ascensão tecnológica chinesa e aos riscos econômicos, políticos e militares que o $5 \mathrm{G}$ da Huawei pode configurar. As sanções à Huawei cumprem um papel estratégico de suma importância nesse contexto. Em um primeiro ponto, as sanções se relacionam com fatores político-econômicos; uma vez que ao longo de toda a história humana, o desenvolvimento de novas tecnologias acabou por conferir vantagem a quem primeiro se mostrou hábil a propulsionar seus interesses por meio dos novos inventos. O Estado que irrompe a nova era tecnológica na qualidade de pioneiro passa a ter vantagem produtiva e maior capacidade de internalizar capitais, dado a alta rentabilidade que oferece; o que se reflete num acréscimo de capacidade de acúmulo de poder.

O pioneirismo das novas tecnologias se associa com o capital político e ganhos de capacidade de incremento de poder militar, possibilitando paulatinamente se estabelecer em uma posição de liderança global - tal qual ocorreu com a Inglaterra no século XIX e os EUA no século XX. Sendo assim, estabelecendo-se a versão chinesa do $5 \mathrm{G}$ como base da Indústria 4.0, a China tenderia a ter ganhos crescentes de poder no sistema internacional - o que é abissalmente ofensivo a perspectiva de jogo de soma zero do realismo adotado 
na política externa dos EUA no governo Trump - onde os ganhos de um representam as perdas de outro.

Embora os ganhos econômicos relacionados a tecnologia 5G se mostrem suficientes para uma intervenção norte-americana por meio de sanções, a perspectiva militar direta existente por trás da tecnologia 5G não pode ser ignorada. Num mundo onde o confronto direto entre duas potências nucleares poderia trazer um nível de destruição incalculável, um novo modelo de guerra que conjugue tecnologias disruptivas e outros meios são uma realidade.

Majerowicz (2020) salienta que as tecnologias informacionais contemporâneas - TICs - são um elemento central para o poder estrutural contemporâneo, pois elas sustentam a Revolução dos Assuntos Militares, a Indústria 4.0 e o aprimoramento tecnológico dos aparatos repressivos domésticos do estado. A autora salienta seu caráter fundamental tanto nas armas de precisão, como para a transformação de táticas e de estratégias militares em novas formas de guerra - tais como a guerra eletrônica e a ciberguerra. Outrossim, por meio das TICs existe a possibilidade de se afetar a opinião pública - tal qual visto nos últimos processos eleitorais ao redor do mundo.

Embora sejam anteriores, o uso de Vants, principalmente pelos EUA, tem se acentuado rapidamente desde o atentado de 11 de setembro de 2001; o que se deve ao amplo desenvolvimento das TICs. Entre os anos de 2004 e 2014, mais de 370 ataques foram realizados com o uso de Vants, provocando mais de 3000 vítimas. Dentre os mortos, aproximadamente $22 \%$ seriam civis e crianças, e quase $80 \%$ são supostamente militantes. Esses ataques atingiram o seu ápice durante a administração Obama. Nesse período, mais de 330 ataques foram realizados, alcançando o pico de 122 no ano de 2010 (New America Foundation 2014).

Ao olhar para o futuro que surge no horizonte próximo, Barreiros (2019) detalha que, devido ao incremento tecnológico, o conceito de drones deve ir além dos Vants, abarcando todo tipo de plataforma terrestre, aérea ou naval operada à distância, com graus variados de autopilotagem e capacidade decisória tática. Incremento esse que tende a levar que se trate as munições guiadas e/ou 
inteligentes (G-RAMMs, guided rockets, artillery, mortars and missiles) a partir de um ponto de vista comum. Barreiros $(2019$, p. 16) relata que:

\begin{abstract}
A proliferação da produção e do uso de munições inteligentes (bem como os VANTs) já representa um sério desafio ao equilíbrio estratégico convencional $\mathrm{e}$, a tirar pelas forças armadas chinesas, poderão constituir nessa primeira metade do século XXI uma "quarta força" em adição às já tradicionais: aviação, marinha e exército.
\end{abstract}

A massificação do uso de Vants tende a resultar no enxameamento (swarming), onde se terá uma atuação conjunta de um alto números de unidades autônomas - fruto do incremento de novas capacidades e da diminuição de custos para a produção de tais equipamentos (Barreiros 2019, p.22)

Os enxames permitirão uma ação cooperativa de um grande número de equipamentos militares autônomos, semiautônomos e automáticos, atuando de forma inteligente, demonstrando uma "inteligência emergente" derivada de dispositivos sensoriais e decisórios integrados no que pode ser compreendido como "internet das coisas militares" (Barreiros, 2019). De forma que os componentes de um enxame estarão conectados entre si, a outros enxames, bem como veículos, sensores, robôs e dispositivos pessoais empregados por soldados humanos, conectados com redes de logística (munições, provisões, medicamentos etc.) constituindo uma evolutiva consciência interoceptiva num organismo que une componentes biológicos e eletrônicos (Barreiros 2019, p.23).

Uma estratégia baseada no enxameamento irá requerer um amplo desenvolvimento no campo da inteligência artificial, uma vez que a demanda para o ideal funcionamento ultrapassa as capacidades cognitivas humanas. Sendo assim, "prioritário que as plataformas militares reunidas em um enxame venham a contar com um grau suficiente de autonomia a ponto de realizarem tarefas básicas e de decidirem acerca de cursos de ação orientados por protocolos táticos gerais", restando ao controlador humano a função de comando na retaguarda (Barreiros, 2019, p.26).

Outro ponto de extrema importância - principalmente devido as acusações que basearam as sanções - é no tocante à proteção das redes de computação e informação de espionagem e roubos (conhecida como "cibersegurança"). Após os ataques terroristas do 11 de setembro em Nova York, diante do contexto da Guerra ao Terror do governo Bush, o desenvolvimento de 
tecnologias biométricas, de comunicação e de monitoramento se deu de maneira muito rápida, movidas por um senso de perigo iminente e de emergência. $\mathrm{O}$ emprego de tais tecnologias buscava levar a cabo a filtragem daqueles percebidos como perigosos, porém havendo reconhecida imprecisão na definição do conceito de inimigos, podendo abarcar a qualquer um, cuja subjetividade dos parâmetros dos agentes responsáveis pelo monitoramento assim nominasse. A fim de monitorar esses perigos invisíveis e iminentes, as agências de segurança dos Estados passaram a apoiar medidas provisórias e decretos executivos por parte de governos que flexibilizavam leis e direitos, tornando possível ações preventivas, antes que novos ataques ocorressem, configurando aquilo que Agamben (2003) considera como sendo práticas de exceção.

O que possibilitou que as agências de inteligência norte-americanas tivessem acesso a um número praticamente ilimitado de dados que circulavam pela infraestrutura de Internet estadunidense. O complexo militar-cibernético foi criado com a junção das principais agências militares de inteligência e pelas agências de força policial dos EUA, aliadas às principais empresas privadas de comunicação dos Estados Unidos (e do mundo) e seus equipamentos. Passando a NSA a deter uma capacidade de espionar o mundo inteiro sem que agentes fossem enviados para fora dos EUA. Isso devido ao fato que o enorme fluxo de dados gerado pelas principais e mais populares empresas de telecomunicação passava por equipamentos localizados nos EUA. Equipamentos que passavam a estar acessíveis às ferramentas de vigilância da NSA.

Posteriormente, a Lei de Proteção à América (Protect America Act) de 2007 ampliou os poderes das agências de inteligência, permitindo pleno acesso a instalações de empresas privadas em solo americano. Permitiu a mineração de dados de maneira mais ampla e complexa, empreendida por softwares capazes de realizar contact chaining (um método de mapeamento de contatos entre pessoas, bem como da interação e relação entre elas, realizada por camadas ou níveis). Como resultado, a Lei de Proteção à América, seguido pelas emendas a Lei de Vigilância de Inteligência Estrangeira (Foreign Intelligence Surveillance Act - FISA) de 2008, lançaram as bases para o sistema massivo de vigilância global mais sofisticado e robusto até então, o PRISM. Empresas como 
Microsoft, Yahoo, Google, Facebook e YouTube, responsáveis por quantidades gigantescas do tráfego de dados da internet, dentro e fora dos EUA (Harris, 2014, p.44), aderiram ao programa PRISM.

Como Harris (2014, p. 44-45) explica, na internet a informação é fragmentada em pacotes de dados e enviada de maneira dispersa por caminhos mais eficientes e rápidos, sendo reagrupada no seu destino; esse destino, contudo, é frequentemente o servidor das próprias empresas que oferecem serviços de internet. Por exemplo, ao se enviar um e-mail por um endereço eletrônico da Google ("gmail"), o destino final são os servidores da Google, e não o destinatário da mensagem - o que possibilita o monitoramento pela NSA. Dentro dessa realidade factual, a NSA se vê dotada de um poder de vigiar e espionar, quase que sem limites, uma quantidade gigantesca de usuários da internet (civis, militares, chefes de Estado, empresas públicas e privadas), de todas as partes do globo.

O que se vê é uma crescente importância e um crescente investimento em tecnologias de monitoramento e vigilância dos meios digitais vivenciados desde o pós-11 de setembro, que se manteve em crescimento em importância dentro da estrutura de segurança norte-americana, como apontam os dados do governo Obama.

A análise da cibersegurança demanda que pensemos também nos aspectos materiais constituintes da Internet: os cabos óticos submarinos que constituem a rede, seguido dos servidores, e finalmente grandes empresas e companhias fabricantes de tecnologias que possibilitam acesso à internet, como modens, roteadores, softwares e hardwares. Bauman (2014) aborda a questão dessa materialidade estratégica do espaço virtual, aponta que embora o foco quando se discute cibersegurança esteja voltado para softwares e perícia em codificação, os hardwares também são de suma importância. Estando os discos de armazenamento, os cabos submarinos e demais elementos tecnológicos e de engenharia da maquinaria a serviço da liberdade de comunicação e do monitoramento e controle (Bauman et al, 2014, p.139).

A importância da materialidade do assunto fica mais nítida ao analisarmos como o governo dos EUA passou a tratar a infraestrutura do setor nos anos recentes, em especial no governo Obama. Em maio de 2009, numa conferência 
na Casa Branca, Obama profere um discurso sobre o novo status que a cibersegurança iria gozar em sua administração:

Minha administração irá seguir uma nova abordagem para dar
segurança à infraestrutura digital da América. [...] De agora em
diante, nossa infraestrutura digital - as redes e computadores dos
quais dependemos todos os dias - será tratada como deveria; com
valor estratégico nacional. Proteger essa infraestrutura será uma
prioridade de segurança nacional. (Obama apud Harris 2014 ,
p.156. tradução livre)

Assim, toda a infraestrutura digital dos EUA - as redes e computadores dos quais se dependem todos os dias - seriam tratados com valor estratégico nacional. Passando a proteção dessa infraestrutura a ser uma prioridade de segurança nacional (Harris, 2014). Cerca de um mês depois, o então Secretário de Defesa, Robert Gates, anuncia a criação do US Cyber Command, também conhecido como CyberCom. O CyberCom conferiu aos agentes de cibersegurança e à sua matéria grande importância, figurando o ciberespaço como uma das outras quatro esferas de guerra reconhecidas pelo governo estadunidense; mar (Marinha), terra (Exército), ar (Aeronáutica) e espacial (NASA), e agora ciberespaço (CyberCom). Mais ainda, sua criação demonstra a disposição do governo dos EUA de pensar o ciberespaço como uma matéria predominantemente estratégica e de domínio militar. A decisão do presidente Obama de transformar a infraestrutura digital do país em matéria de segurança estratégica nacional englobava em grande parte as empresas e as companhias civis e privadas.

Em 2010, durante o governo Obama, a preocupação quanto a emergência de guerras cibernéticas constou no Quadrennial Defense Review (QDR, 2010) e no NSS-2010. O NSS-2010 detalha que as ameaças de segurança cibernética representam uma das mais sérias questões de segurança nacional, de segurança pública e de segurança econômica. Aponta que as mesmas tecnologias que capacitam o Estado norte-americano a liderar e criar, também capacitam aqueles que o intentam perturbar e destruir. Sendo o domínio em tais setores tecnológicos a permitirem a superioridade militar dos EUA. Dependendo a vida diária e a superioridade militar da infraestrutura digital, se faz necessário considerá-la como um ativo nacional estratégico, e, por conseguinte, protegê-la - salvaguardando a privacidade e liberdades - conferindo-lhe o status de 
prioridade de segurança nacional. Buscando assim, deter, prevenir, detectar e defender-se (NSS-2010).

Os vazamentos de informações confidenciais da NSA, realizados por Edward Snowden, mostraram que o uso da ampla rede e mecanismos de vigilância foi muito além dos objetivos inicialmente acordados entre os EUA e seus aliados para o combate ao terrorismo global. Os vazamentos revelaram, entre outras coisas, o uso dessa megaestrutura cibernética por parte dos EUA de modo a exercer: espionagem industrial, vigilância de populações para identificar perfis de consumidor, bem como de tendências políticas relativas aos possíveis resultados eleitorais destes países, além de espionagem de mensagens pessoais de importante figuras políticas, não só de países europeus, mas também de outros, como o Brasil (Bauman, 2014).

O caso levou a percepção de como as assimetrias do elemento material não só interferem nas capacidades de cada agência de inteligência, mas também demonstra a existência de relações de poder e que essas não são negligenciáveis. O que confere extrema relevância ao fato de a infraestrutura do novo modelo de internet que emerge, sem a interferência norte-americana, tenderia a contar com uma ampla gama de componentes tecnológicos chineses - visto que o 5G desenvolvido pela Huawei possui larga vantagem sobre as versões concorrentes europeias e também devido as políticas do Estado chinês de financiamento de infraestrutura ao redor do mundo, mas principalmente na zona da Eurásia e do continente africano - regiões de extrema importância na tradição geopolítica norte-americana.

A Huawei e o governo chinês, anos antes de 2019, já atuavam de modo a investir na infraestrutura das TICs, e a influenciar a regulamentação e as especificações no âmbito internacional da tecnologia $5 \mathrm{G}$, por meio da estratégia que Adam Segal chamou de Cyber diplomacia chinesa (Segal, 2016; Segal, 2017).

Como detalhado em Segal (2017), o governo chinês tem usado o comércio e o investimento em infraestrutura de TICs com fins econômicos, mas também como ferramenta política indireta. O que se vê é uma atuação chinesa na África, Sudeste Asiático e Ásia Central buscando acesso à mercados, bem como criar apoio para a política externa de Pequim e normas do ciberespaço. 
Embora o investimento nem sempre se transforme em influência, ainda assim, há uma preocupação no âmbito internacional no tocante a possibilidade de os laços econômicos fornecerem à Pequim influência direta e indireta, além de alavancagem. Simplesmente fornecendo fontes alternativas de financiamento, Pequim pode minar os esforços dos EUA e da Europa no desenvolvimento de normas (Segal, 2017).

A ajuda dos EUA e da Europa muitas vezes vêm com condicionalidades em relação à democracia, transparência e responsabilidade. Como o Instituto de Estudos de Segurança da União Europeia (IESUE) colocou em seu relatório sobre capacitação cibernética: "A realidade é que, como doador, a União Europeia não opera no vácuo e, portanto, deve ser prudente; os destinatários podem ir para a China para financiamento se acharem que a UE espera muito deles." (ISS apud Segal 2017, p.12 tradução nossa) A título de exemplificação, Segal (2017, p.12) detalha que já em 2010, as empresas de telecomunicações chinesas Huawei e ZTE atuaram em cinquenta países africanos, fornecendo serviços de comunicações para mais de 300 milhões usuários africanos.

As duas empresas chinesas possuem centros de treinamento em nove países africanos e construíram redes nacionais de comunicações de fibra óptica e redes de governo eletrônico para mais de vinte países. Tal movimento é financiado via empréstimos preferenciais e créditos de comprador fornecidos às telecomunicações como parte da política de "sair" para promover a internacionalização de firmas chinesas (Segal, 2017, p.12) Grande parte do investimento e comércio chinês atual ocorre como parte do programa Um Cinturão, Uma Estrada (One Belt, One Road - OBOR), uma estratégia de desenvolvimento que visa a conectividade e cooperação em países entre a China e a Eurásia.

O OBOR possui duas ramificações: o Cinturão Econômico da Rota da Seda, que conecta a China ao Golfo Pérsico, Mediterrâneo e Oceano Índico por terra; e a Rota da Seda Marítima do Século XXI, que liga hidrovias regionais. Documentos oficiais chineses enfatizaram a necessidade para construir uma "rota da seda da informação" através de cabos ópticos transfronteiriços e outras redes de linhas troncais de comunicações, projetos de cabos ópticos submarinos transcontinentais e comunicação espacial (via satélite) (Segal, 2017). Em 
dezembro de 2016, o Ministério da Indústria e Tecnologia da Informação projetou a construção e atualização das redes de telecomunicações na África, com investimentos previstos para totalizar US $\$ 173,73$ bilhões (Segal, 2017). Tendo uma série de outros investimentos realizados por empresas chinesas em nós ao longo do Belt and Road, e uma série de outros investimentos na África e no Sudeste asiático já planejados (Segal, 2017).

A China Comservice, uma subsidiária da China Telecom, anunciou a "Construção conjunta da super estrada da informação da África entre a China e a África (Joint Construction of Africa's Information Superhighway between China and Africa), com um investimento orçado em US\$ 15 bilhões, que visa alcançar 150.000 quilômetros cobertura de cabo óptico em quarenta e oito países africanos. A China Unicom, uma operadora de telecomunicações chinesa, trabalha de modo a instalar cabos ópticos para conectar a Ásia Central, Sudeste Asiático, África e América do Sul (China go Abroad 2016). Em 2016, a ZTE concordou em adquirir a empresa turca Netas Telekomünikasyon por até US\$ 101,28 milhões, visando expandir a sua atuação nos principais mercados coberto pelo OBOR. (Perez, 2016)

Desde que entrou na Organização Mundial do Comércio (OMC), a China passou a atuar para influenciar padrões de tecnologia em software, hardware e de comunicação. Segundo Segal (2017), os legisladores chineses acreditavam que ao controlarem um padrão isso garantiria a captura de grande parte do valor de mercado. A China tem trabalhado de modo a aumentar sua habilidade e sofisticação em organizações de padrões globais, tendo focado seus esforços na próxima geração de tecnologias de Internet e comunicação - como transparece o envio de grandes delegações para reuniões de normas técnicas.

A China também tem estado ativa na International Telecommunication Union (ITU) trabalhando de forma a liderar o grupo de arquitetura digital - Digital Object Architecture (DOA), um sistema de gestão que pode ser relevante na "Internet das coisas" (McDowell e Goldstein, 2016; Segal, 2017). O número de representantes enviados para as reuniões que visam estabelecer padrões tecnológicos é significantemente maior que o visto habitualmente em outras delegações. Como noticiado pelo Wall Street Journal, a Huawei enviou o dobro de representantes que outras telecomunicações para uma reunião, em 2016, em 
Viena, para definir as capacidades e especificações de celular de quinta geração (5G) (Verbergt, 2017; Segal, 2017).

Como podemos ver, os investimentos chineses na infraestrutura em outros países têm possibilitado a inserção de empresas e componentes chineses na Eurásia e na África, o que não só possibilita um aumento de influência chinesa na região como também altera o quadro de domínio sobre a infraestrutura que até então se encontra sob o poder norte-americano, visto a maior parte dos componentes serem oriundos dos EUA ou de países aliados a ele.

Uma vez que nenhum outro país no mundo conhece mais e melhor as aplicabilidades que podem ser dadas à internet - tanto no controle de armas de ataques à distância, quanto em complexos sistemas de vigilância e espionagem mundial -, a preocupação dos EUA - visto sua ótica realista ofensiva - em conter o avanço chinês na difusão de seus componentes na infraestrutura da internet global se mostra plenamente pertinente dentro da importância conferida à internet e a sua infraestrutura na estrutura de poder dos EUA.

\section{Considerações finais}

A partir do exposto no presente trabalho, percebe-se o momento atual como decisivo para a manutenção do poder americano, uma vez que a China tem buscado, e com muitos sucessos, alcançar o patamar dos EUA em termos tecnológicos. Desde a sua ascensão econômica e tecnológica ocorrida no final do século 19, os EUA sempre ocuparam o posto de maior potência tecnológica, em especial quanto às TICs. É inegável que, hoje, os EUA ainda detêm o posto de maior potência tecnológica mundial, restando ainda um longo caminho a ser percorrido pela China.

Porém, é inegável também o grande êxito alcançado pelo projeto chinês de desenvolvimento no seguimento das TICs, o país hoje está na vanguarda tecnológica intrinsicamente ligado as TICs, tanto para uso militar quanto civil. Em função disso, os EUA fazem um movimento totalmente lógico e esperado dentro da visão realista ofensiva adotada nas suas relações internacionais durante o governo Trump, que consiste na tentativa de bloquear ou pelo menos conter 0 
avanço tecnológico chinês. Para alcançar tal fim, os EUA impõem barreiras comerciais e financeiras para limitar o acesso chinês a componentes e serviços essenciais oriundos de empresas norte-americanas utilizando a sua influência sobre União Europeia, outros países e regiões subordinados para reforçar esta política.

O caso da Huawei pode ser visto como emblemático justamente por unir distintos aspectos desse embate. O surgimento da Huawei se entrelaçou com a busca pela redução dos custos de produções das economias centrais, que ao adotarem o modelo de produção modular acabaram por transformar a China na 'fábrica do mundo', possibilitando que este país colocasse em prática um projeto de desenvolvimento tecnológico centrado na absorção de tecnologia estrangeira. Como resultado desse projeto, a China se transformou na segunda maior potência mundial em poucas décadas e alcançou o posto de desafiante tecnológico.

Outro ponto que torna o caso bem simbólico é o fato de o fundador da Huawei ter sido um ex-militar chinês, o que somado aos esforços do governo chinês visando ao crescimento da empresa, nutre a ideia de proximidade entre as partes - governo, militares chineses e Huawei. E como conclui Trebat e Medeiros (2015, p.546), "a presença do Estado em todas as etapas do processo de inovação na China ajuda a promover mais consistentemente a integração militar-civil". Desde o final do século 19, os EUA sempre estiveram na vanguarda tecnológica no tocante aos meios de produção e isso é especialmente o caso em relação à infraestrutura da informação.

Como demonstrado, a infraestrutura da internet está intimamente ligada a capacidade de atuação via Vants e de monitoramento de dados pelas agências de inteligência dos EUA. Diante da realidade de que os conflitos e ataques entre as grandes potências tornam-se cada vez mais multidimensionais, é de se esperar que os EUA não poupem esforços para manterem sua larga vantagem na corrida de capacidade cibernética, visto que essa torna-se cada dia mais central na perspectiva militar norte-americana. Essa perspectiva inclui manter a infraestrutura da internet global com a menor quantidade possível de componentes chineses desenvolvidos para a tecnologia $5 \mathrm{G}$ e 0 mais longe possível dos padrões tecnológicos desejados pela China. 
Todavia, o fato da versão da tecnologia $5 G$ desenvolvida pela Huawei ofertar um desempenho tão superior as versões da concorrência e ser ofertada a um custo significativamente mais baixo dificulta o objetivo dos EUA junto aos outros países centrais. Como resultado desse quadro, temos que $60 \%$ dos países da União Europeia já adotaram a tecnologia $5 G$ da Huawei. Tal dificuldade se soma ao desafio trazido pela estratégia chinesa de ofertar crédito em condições mais acessíveis a países periféricos, em especial no tocante a projetos de infraestrutura, o que acaba por facilitar que seus equipamentos mais eficientes e com um custo menor, permeiem a infraestrutura da internet de tais países.

Por fim, fica claro que os EUA buscam seguir o modelo de exercício de poder que os conduziram ao posto mais alto do tabuleiro global, entendendo que a manutenção de seu poder exige a busca constante da acumulação de mais poder. Como ressalta Fiori (2005) na esfera da competição interestatal, quem não sobe, cai, como foi pós-Segunda Guerra e continua sendo verdade pósGuerra Fria. Por outro lado, a China parece ter reaprendido a lição - bem conhecida por seus antepassados milenares - que é necessário se manter na vanguarda da inovação e da tecnologia para se manter forte e altiva.

\section{Referências Bibliográficas}

BARREIROS, Daniel. Projeções sobre o Futuro da Guerra: Tecnologias disruptivas e mudanças paradigmáticas (2020 - 2060). 2019 Discussion Paper $025 \quad 1 \quad 2019 \quad$ IE-UFRJ. https://www.ie.ufri.br/images/IE/TDS/2019/TD IE 0252019 BARREIROS.pdf Acesso em 01 de agosto de 2021 às $12 \mathrm{~h} 35$.

BAUMAN, Zygmunt. et al. After snowden: rethinking the impact of surveillance. $2014 . \quad$ Disponível em: http://citeseerx.ist.psu.edu/viewdoc/download?doi=10.1.1.840.3683\&rep=rep1\&t ype=pdf Acesso: 01 de agosto de 2021 às 13:20

BRZEZINSKI, Z (2012a). Strategic Vision. America and the crisis of Global Power. New York: Basic Books.

CARR, E.H. Vinte anos de crise: 1919-1939. 2.ed. Brasilia: UNB, 1981.

FIORI, José Luís. Formação, Expansão e Limites do Poder Global. In: O Poder Americano. Rio de Janeiro: Editora Vozes, 2005. 
A síndrome de babel e a nova doutrina de segurança dos Estados Unidos. Revista Tempo do Mundo, Volume 4, Número 2 - Julho 2018. IPEA, 2018

HARRIS, Shane. @War:The rise of the military-internet complex. Houghton Mifflin Harcourt, New York, 2014.

KISSINGER, H. Ordem Mundial. Rio de Janeiro: Objetiva, 2014.

LEÃO, Valdemar Carneiro. Prefácio. In: China em transformação: Dimensões econômicas e geopolíticas do desenvolvimento. IPEA Disponível: https://www.ipea.gov.br/portal/images/stories/PDFs/livros/livros/150918 livro C hina em transformacao.pdf. Acesso em 01 de agosto de 2021 às $12 \mathrm{~h} 30$

MAJEROWICS, E. As tecnologias da informação e comunicação na disputa entre China e Estados Unidos. Jornal dos Economistas. Rio de Janeiro v. 365 p 10-11, março 2020.

MEARSHEIMER, John. The Great Delusion - Liberal Dreams and International Realities. Yale University Press, 2018.

MENN, Joseph. Plummer quoted in Joseph Menn, "White House-ordered Review Found No Evidence of Huawei Spying: Sources," Reuters, October 18, 2012. Disponível: https://www.reuters.com/article/ctech-us-huawei-spyingidCABRE89G1Q920121018. Acesso em 01 de agosto de 2021 às $12 \mathrm{~h} 31$

MORGENTHAU, Hans J. A política entre as nações: a luta pela guerra e pela paz. Brasília: Editora Universidade de Brasília/ Instituto de Pesquisa de Relações Internacionais; São Paulo: Imprensa Oficial do Estado de São Paulo, 2003

NEW AMERICA FOUNDATION. Drone Wars Pakistan: Analysis. Disponível: http://natsec.newamerica.net/drones/pakistan/analysis. Acesso em 12 abr. 2014 às 09:00

NOGUEIRA, Isabela. Políticas de fomento à ascensão da China nas cadeias de valor globais. In: China em transformação: Dimensões econômicas e geopolíticas do desenvolvimento. IPEA Disponível: https://www.ipea.gov.br/portal/images/stories/PDFs/livros/livros/150918 livro C hina em transformacao.pdf. Acesso em 01 de agosto de 2021 às $12 \mathrm{~h} 35$

OUT OF SIGHT, OUT OF MIND. 2014. Attacks.Plataforma Digital. Disponível: http://drones.pitchinteractive.com. Acesso em 16 maio 2014.

PADULA, Raphael. O debate geoestratégico nos EUA: o lugar da Eurásia, do hemisfério ocidental e do México. R. Esc. Guerra Nav., Rio de Janeiro, v. 24, n. 2, p. 395-418. maio/agosto. 2018.

PEREZ, Bien. “China's ZTE Takes Over Netas for \$101m, Eyes Expansion in Turkey". South China Morning Post, December 6, 2016. Disponível: 
www.scmp.com/tech/china-tech/article/2052271/chinas-zte-takes-over-netas$101 \mathrm{~m}$-eyes-expansion-turkey. Acesso em 01 de agosto de 2021 às $12 \mathrm{~h} 30$

PIRES, Marcos Cordeiro. O Brasil, o Mundo e a Quarta Revolução Industrial: reflexões sobre os impactos econômicos e sociais. REVISTA DE ECONOMIA POLÍTICA E HISTÓRIA ECONÔMICA, v. 40, p. 5-36, 2018.

Robert M. McDowell and Gordon M. Goldstein, "The Authoritarian Internet Power Grab", Wall Street Journal, October 25, 2016, www.wsj.com/articles/theauthoritarian-Internet-power-grab-1477436573.

SANDERSON, Henry; FORSYTHE, Michael. China's superbank: debt, oil and influence - how China Development Bank is rewriting the rules of finance. Singapore: Wiley; Bloomberg Press, 22 Jan. 2013. (Versão para Kindle).

SANTANA, Ivone. Na guerra do $5 \mathrm{G}$, Huawei já tem $60 \%$ da EU. Valor Econômico. Disponível: https://valor.globo.com/empresas/noticia/2020/12/29/na-guerra-do-5g-huaweija-tem-60-da-ue.ghtml. Acesso em: 22/03/2021)

SEGAL, Adam. Chinese Cyber Diplomacy in a new era of uncertainly. New York: Public Affairs, 2017

SEGAL, Adam. The Hacked Word Order. New York: Public Affairs, 2016

The White House (2017), National Security Strategy of the United States of America 2017 (Washington: The White House).

TREBAT, Nicholas M.; MEDEIROS, Carlos. Modernização Militar no Progresso Técnico e na Inovação Industrial Chinesa. In: China em transformação: Dimensões econômicas e geopolíticas do desenvolvimento. IPEA

Disponível:

https://www.ipea.gov.br/portal/images/stories/PDFs/livros/livros/150918 livro china e $\mathrm{m}$ transformacao.pdf. Acesso em 01 de agosto de 2021 às $12 \mathrm{~h} 40$

VERBERGT, Matthias. "China's Huawei Battles to Own the Next Generation of Wireless Technology", Wall Street Journal, February 26, 2017, https://www.wsj .com/articles/chinas-huawei-battles-to-own-the-next-generationof-wireless-technology-1488114002.

WINTOUR, Patrick. Europe divided on Huawei as US pressure to drop company grows. The Guardian UK. Disponível: https://www.theguardian.com/technology/2020/jul/13/europe-divided-on-huaweias-us-pressure-to-drop-company-grows. Acesso em 22 mar. 2021. 